Article

\title{
Comparative Analysis of Three Forest Management Plans in Southern Mexico
}

\author{
Wenceslao Santiago-García ${ }^{1, *(0)}$, Lourdes Bautista-Pérez ${ }^{1}$, Gerardo Rodríguez-Ortiz ${ }^{2}$ (D), \\ Gerónimo Quiñonez-Barraza ${ }^{3}{ }^{\circledR}$, Faustino Ruiz-Aquino ${ }^{1}$ (D), Mario Ernesto Suárez-Mota ${ }^{1}$, Elías Santiago-García ${ }^{4}$, \\ Tania Leyva-Pablo ${ }^{5}$, Melquiades Cortés-Pérez ${ }^{5}$ and Manuel de Jesús González-Guillén ${ }^{6}$
}

1 División de Estudios de Postgrado-Instituto de Estudios Ambientales, Universidad de la Sierra Juárez, Avenida Universidad s/n, Ixtlán de Juárez 68725, Mexico; bautista.geminis_26@hotmail.com (L.B.-P.); ruiz.aquino@unsij.edu.mx (F.R.-A.); mesuarez@unsij.edu.mx (M.E.S.-M.)

2 División de Estudios de Posgrado e Investigación-Tecnológico Nacional de México/Instituto Tecnológico del Valle de Oaxaca, Ex Hacienda de Nazareno s/n, Xoxocotlán 71230, Mexico; gerardo.rodriguez@voaxaca.tecnm.mx

3 Centro de Investigación Regional Norte Centro, Campo Experimental Valle del Guadiana, Instituto Nacional de Investigaciones Forestales, Agrícolas y Pecuarias, Carretera Durango-Mezquital km 4.5, Durango 34170, Mexico; quinonez.geronimo@inifap.gob.mx

4 Dirección Técnica Forestal de la Comunidad de Ixtlán de Juárez, Oaxaca, Carretera Oaxaca-Tuxtepec s/n, Ixtlán de Juárez 68725, Mexico; forestal_esg@live.com

5 Doctorado en Ciencias Agropecuarias, Universidad Autónoma Metropolitana, Calzada del Hueso 1100, Coapa, Villa Quietud, Coyoacán 04960, Mexico; tanialeyvapablo@gmail.com (T.L.-P.); yaguar.jo@gmail.com (M.C.-P.)

Citation: Santiago-García, W.; Bautista-Pérez, L.; Rodríguez-Ortiz, G.; Quiñonez-Barraza, G.;

Ruiz-Aquino, F.; Suárez-Mota, M.E.; Santiago-García, E.; Leyva-Pablo, T.; Cortés-Pérez, M.; González-Guillén, M.d.J. Comparative Analysis of Three Forest Management Plans in Southern Mexico. Forests 2022, 13, 393. https://doi.org/10.3390/ f13030393

Academic Editor: Jose G. Borges

Received: 10 February 2022

Accepted: 24 February 2022

Published: 27 February 2022

Publisher's Note: MDPI stays neutral with regard to jurisdictional claims in published maps and institutional affiliations.

Copyright: (c) 2022 by the authors. Licensee MDPI, Basel, Switzerland. This article is an open access article distributed under the terms and conditions of the Creative Commons Attribution (CC BY) license (https:// creativecommons.org/licenses/by/ $4.0 /)$.
6 Postgrado en Ciencias Forestales, Colegio de Postgraduados, Carretera México-Texcoco km. 36.5, Montecillo 56230, Mexico; manuelg@colpos.mx

* Correspondence: wsantiago@unsij.edu.mx; Tel.: +52-951-220-3466

\begin{abstract}
In the middle of the last century, the Mexican government applied a forest administration policy based on state control through concessions to parastatal enterprises. In the 1980s, communities began to regain control of their forests and promote community forestry, with Ixtlán playing a leading role. This study compared three forest management plans (FMPs) that have been implemented in the community of Ixtlán de Juárez, in southern Mexico, and their contributions to the productivity and conservation of forest resources. The information was obtained from three FMPs, considering the silvicultural regimes, the original stand or sub-stand structure, and the species that promoted cutting regeneration. These FMPs represent different management periods; the forest inventory of the first FMP indicates the condition of the forest originated under state control, while the two subsequent ones evaluate the condition of the forest under community forestry. Sub-stand variables of the three FMPs were compared using the nonparametric Kruskal-Wallis test. The results indicated that, in the first FMP, the sub-stands were of old growth, and intensive thinning was applied. In the two subsequent plans, alternate strip clearcutting and single-tree selection were implemented. It was shown that, with increased management intensity in the sub-stands, better characteristics were obtained in terms of increment in basal area and volume variables, promoting regeneration and establishment of Pinus and displacing dominance of Quercus genus, without affecting forest richness and diversity.
\end{abstract}

Keywords: conservation; community forestry; forest management; forests; Kruskal-Wallis test; land use; productivity; silvicultural regimes; trees

\section{Introduction}

Mexican forest communities are a worldwide model of community forest management for timber production and conservation of forest resources under the form of community forest enterprises (CFEs) [1-3]. In Mexico, the area covered by temperate forests and 
rainforest is estimated at around 64.3 million of hectares, from which there is an average annual production of 6.8 million $\mathrm{m}^{3}$ of roundwood [4]. Of this volume, CFEs contribute around $85 \%[3,5]$.

Approximately $60 \%$ of Mexico's forests belong to local communities [6], which practice autonomy in their management and use [7]. However, in the middle of the last century, a strategy was applied for forest administration based on state control through concessions to parastatal enterprises [8]. In the 1986 forestry law, the forest concession system was annulled [9], and communities' right to use their forest resources was recognized. In addition, the agreement to develop integral forest management plans (FMPs) was established.

In general, community forestry involves the active participation of people from local communities in forestry activities. This emerged in the late 1970s, when the state's control over resources and its ability to protect and manage forests sustainably were questioned as a consequence of concerns about increased deforestation [10]. In Mexico, with the modifications of the 1986 forest law, the communities were given the task of looking for new tools for the use and management of forests, while mitigating environmental impacts and guaranteeing the supply of forest raw material, thus giving way to community forestry [9]. In addition, several silvicultural regimes began to be used to modify the structure and increase productivity of forests communities, mainly using methods such as seed-tree, liberation cutting, precommercial thinning, and commercial thinning.

Some years after the 1986 forest law, modifications to forestry regulations led to passage of the 1992, 2003, and 2018 laws. These laws established the objectives of conservation, protection, restoration, production, management practices, and use, all of which were aimed at achieving optimal and sustainable productivity of forest resources [11]. Likewise, it is recognized that, in forest management, economic, social, and ecological factors must be considered [12]. Therefore, the objectives of forest management in a communal forest also involve social welfare, job creation, and the development of alternative economic activities [3,13].

In the Sierra Juárez, Oaxaca, southern Mexico, in the beginning of the 1980s with the end of the concession to the parastatal enterprise "Fábricas de Papel Tuxtepec" (FAPATUX), which had a 25 year concession in the area, several communities were organized for the utilization and extraction of their forest resources [14-16]. In 1981, the forestry organization "Lic. José López Portillo" was constituted by the communities Ixtlán de Juárez, Capulálpam de Méndez, La Trinidad Ixtlán, and Santiago Xiacui, with the support of FAPATUX, disintegrating in 1988, leaving only Ixtlán de Juárez [17,18]. From 1988 to 1991, the CFE of Ixtlán was restructured, and the "Unidad Comunal Forestal Agropecuaria y de Servicios" (UCFAS) was integrated. By 1991, UCFAS began efforts to have their own technical forestry groups (with community members) and FMPs $[17,19]$.

The community of Ixtlán de Juárez, like other forest communities in Oaxaca, is a representative case of community forest management in Mexico, where logging is the main economic activity $[5,20]$. Therefore, to maintain the productive and conservation values of forest resources, there is a need to evaluate over time the effects of the implementation of silvicultural practices and management regimes. For this reason, some studies have evaluated the structure, richness, and composition of tree species at coarse scales of analysis [21-24], while others have focused on ecosystem functioning by assessing productivity in terms of biomass, carbon, basal area, number of trees, volume, and increment at the stand or sub-stand level [25-29].

The Ixtlán de Juárez community began with its first timber FMP in 1993. This forest management plan used a cutting cycle from 1993 to 2002, aiming to achieve good silvicultural management, as well as forest conservation and creation of sources of employment for the community. In 2004, the second FMP was applied. It was suspended for 2 years due to a pest infestation in several sub-stands of the community forest, but resumed in 2006. The third FMP (2015-2024) is currently under development. Throughout the previous FMPs, various systems and silvicultural regimes have been applied according to the forest's 
conditions and its response to regeneration, growth, and adaptation to the treatments applied.

The main objective of this research was to compare silvicultural and forest measures in the Ixtlán de Juárez forests among three FMPs that have been proposed in the community and how their application has contributed to the productivity and conservation of forest resources.

\section{Materials and Methods}

\subsection{Background of the Study Area}

The study was conducted in the communal forest under management of the community of Ixtlán de Juárez, Oaxaca, Mexico (Figure 1), located within the geographic coordinates $17^{\circ} 18^{\prime} 16^{\prime \prime}-17^{\circ} 30^{\prime} 00^{\prime \prime} \mathrm{N}$ and $96^{\circ} 21^{\prime} 29^{\prime \prime}-96^{\circ} 31^{\prime} 38^{\prime \prime} \mathrm{W}$, ranging in altitude from $2200 \mathrm{~m}$ to $3100 \mathrm{~m}$. Most of the pine-oak forest land area has a humid temperate climate with summer rains, and the pine and oak species are mainly harvested species groups [18,30].

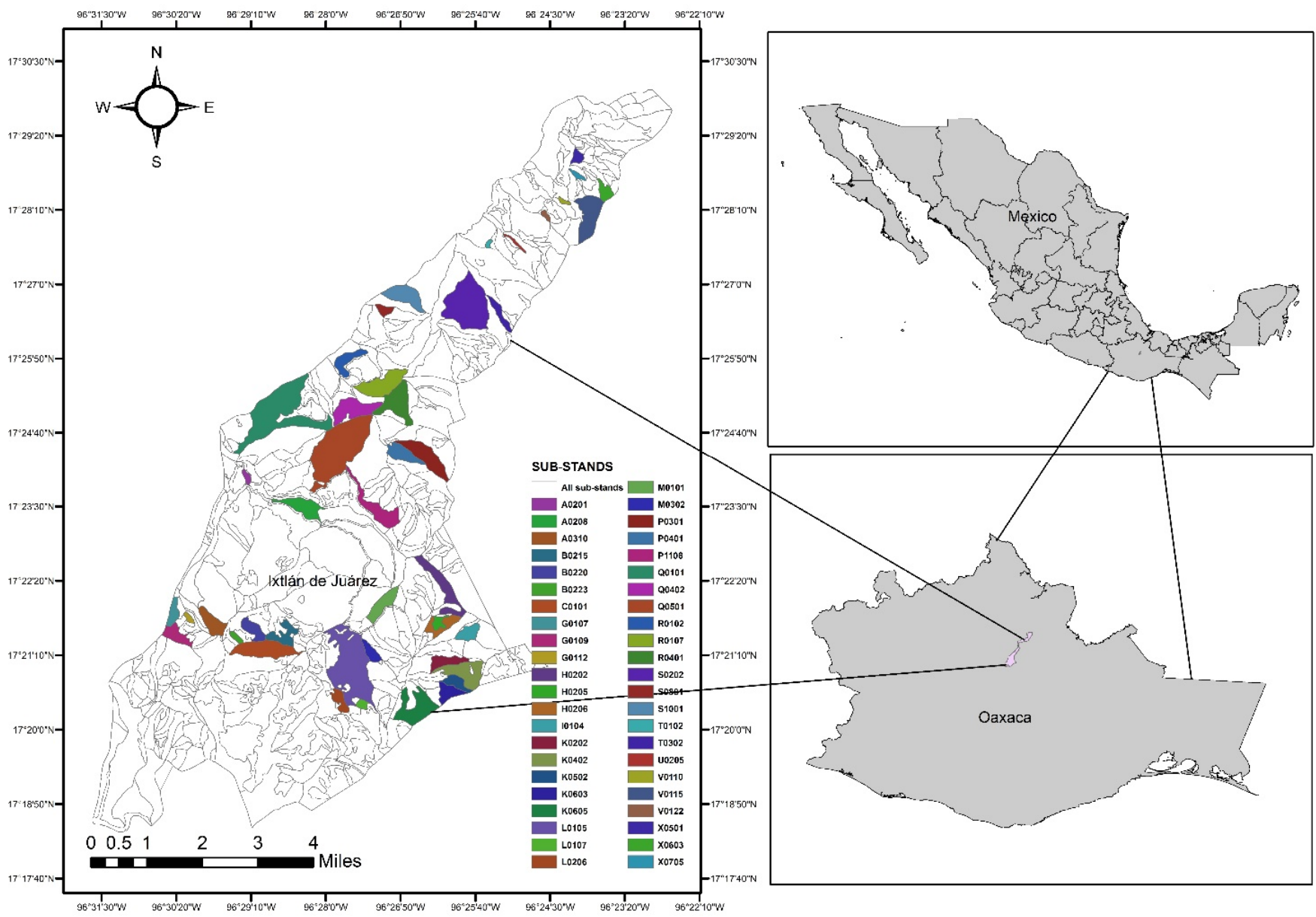

Figure 1. Location of the study area.

In the analytical comparison of the Ixtlán de Juárez community FMPs, data from three forest inventories of forest management planning were used. These datasets support the cutting cycles 1993-2002 (FMP1), 2004-2013 (FMP2), and 2015-2024 (FMP3). The most important applied silvicultural treatments for FMPs were seed-tree and single-tree selection for FMP1, while, for FMP2 and FMP3, strip clearcutting and single-tree selection were applied.

In the inventory for FMP1, around 20000.10 ha sampling plots were measured under a stratified random sampling design. For FMP2, the same sampling design was used, and 1696 sampling plots were evaluated, while, for FMP3, a stratified systematic sampling 
design was implemented where we measured 1081 sampling plots, of which 410.010 ha plots were used to facilitate evaluation of the regeneration response in areas of alternate strip clearcutting.

\subsection{Variables at the Sub-Stand Level of the Three Forest Management Plans}

The variables computed were number of trees $\left(N T\right.$, trees $\left.\cdot \mathrm{ha}^{-1}\right)$, basal area $\left(B A, \mathrm{~m}^{2} \cdot \mathrm{ha}^{-1}\right)$, and volume $\left(\mathrm{Vol}, \mathrm{m}^{3} \cdot \mathrm{ha}^{-1}\right)$, which were contrasted according to forest inventories of each FMP. The analyses obtained in each FMP were at the sub-stand (stand divisions with similar vegetation characteristics) level, by species groups (pine, oak, and other broadleaf trees) and the average values per hectare. The average NT, BA, and $\mathrm{Vol}$ per sampling plot were multiplied by the sampling frame of each sub-stand, thus obtaining the totals of each management unit; with this, the average values of the sub-stand variables per hectare were estimated. In addition, the dominant pine species and the silvicultural treatment applied in each sub-stand by FMP were determined. In the analysis, only those sub-stands that maintained their identity in the three FMPs (same name and same area) were chosen.

Segmentation of the Ixtlán forests has been carried out since 1992, where 18 stands and 135 sub-stands are delimited. The land is classified into four areas with different purposes depending on the characteristics of each site: conservation areas and restricted use (11,120 ha), areas under timber forest management (7355 ha), restoration areas (144 ha), and areas of other uses (691 ha) [31]. For analysis of the variables, 45 sub-stands were selected on the basis of their identification (ID) (Figure 1), the area, and whether they maintained their identity through the three FMPs (Supplementary Table S1), since, for the second and third plans, many of the sub-stands defined in the first FMP were not present or, in some cases, were grouped due to their small area.

\subsection{Data Analysis}

The statistical comparisons of the FMPs and their silvicultural treatments were carried out using the nonparametric Kruskal-Wallis test [32], and the NPAR1WAY WILCOXON procedure was used in $S A S^{\circledR}$ software, version 9.4 [33]. Differences between medians were determined using an a priori critical significance level at $5 \%(\alpha=0.05)$ and adjusting this with Bonferroni correction: $\alpha^{*}=\alpha /(t \times(t-1))$, where $\alpha^{*}$ is the significance level calculated under Bonferroni, and $t$ is the number of FMPs [34]. The variables $N T, B A$, and $V o l$ by sub-stand were analyzed graphically with the "lattice" and "gridExtra" libraries of the statistical program $\mathrm{R}^{\circledR}$, version 4.1.0 [35].

\section{Results and Discussion}

\subsection{Comparison of Sub-Stand Variables of the Three Forest Management Plans}

The comparison of the selected 45 sub-stands in the three FMPs showed that Pinus patula Schiede ex Schltdl. \& Cham. is the most dominant species (Figure 2A). In the case of the third forest inventory, in 31 sub-stands, Pinus patula was the dominant species, followed by Pinus oaxacana Mirov in seven sub-stands. The reported stocks for Pinus patula and for Pinus oaxacana are $462,904.12 \mathrm{~m}^{3}$ total tree volume and $144,458.48 \mathrm{~m}^{3}$ total tree volume, respectively [31]. According to TIASA [17], 45\% of pine stocks are Pinus patula, followed by Pinus oaxacana, Pinus teocote Schied. ex Schltdl. \& Cham., Pinus douglasiana Martínez, and Pinus ayacahuite Ehrenb. ex Schltdl.; in another study, Castellanos-Bolaños et al. [36] determined that Pinus patula is distributed over approximately 5000 ha and is one of the most economically important species due to its rapid growth and wood quality.

According to the first FMP [17], with the data obtained from the first forest inventory and its analysis, it was possible to determine that several of the sub-stands were overmature, and young sub-stands were scarce, while there was an abundance of oaks and other broadleaf trees. This aspect is attributed to the fact that, during the time of concessions and management by the FAPATUX enterprise, logging was clearly selective toward individuals with larger diameters, and necessary stand treatments were not given, promoting the 
growth of other species different from pine species [18]. Ramírez-Santiago [37] pointed out that regeneration of pines is low when the single-tree selection method is used due to their shade intolerance, while it favors establishment of oaks and other broadleaf trees.

(A)

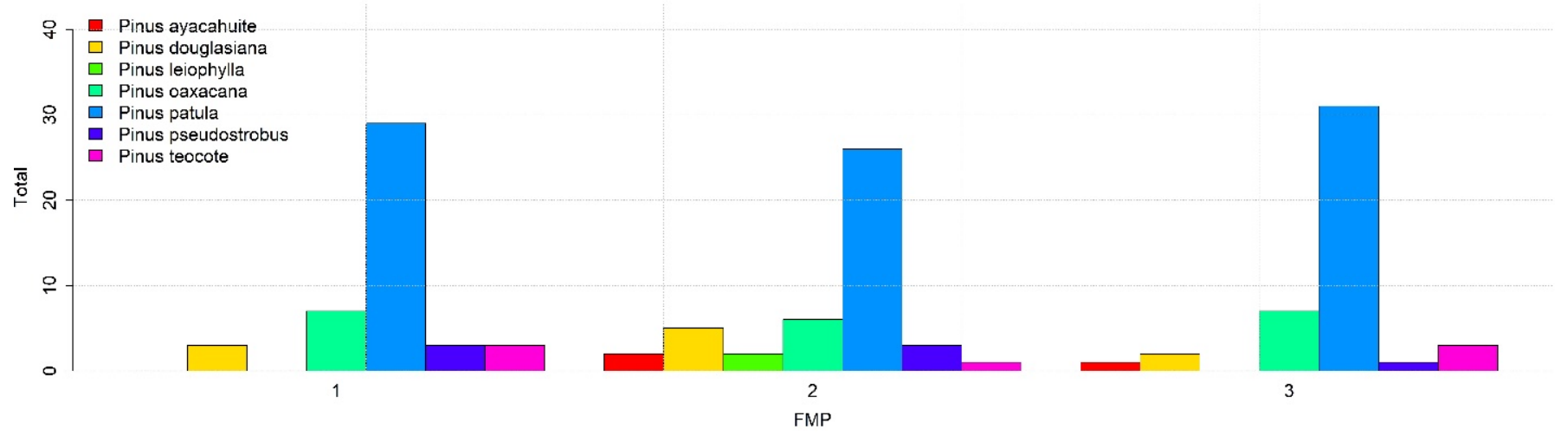

(B)

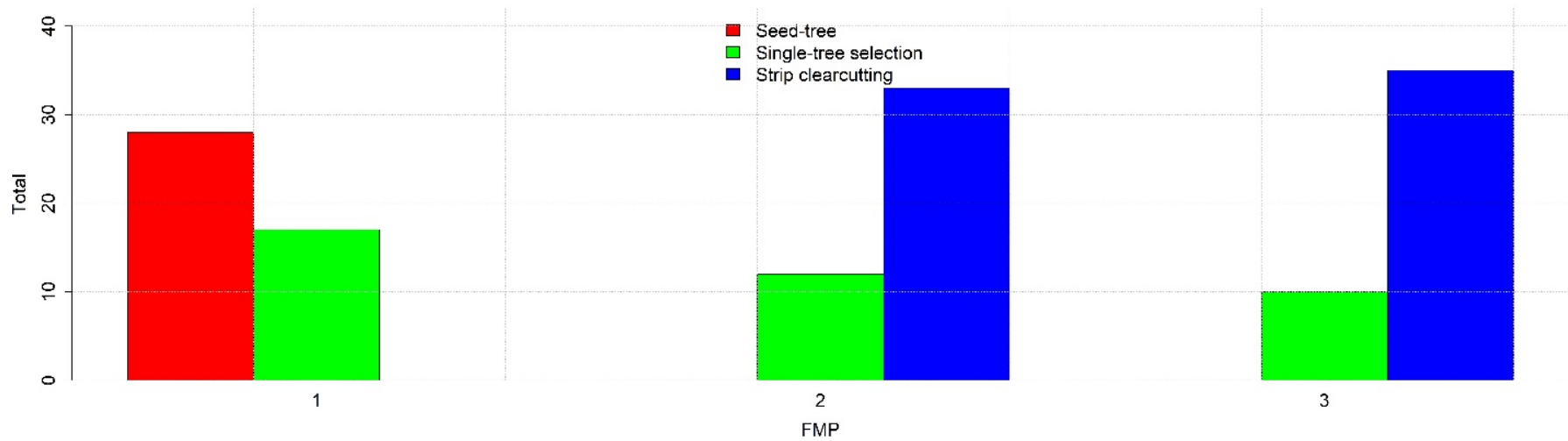

Figure 2. Dominant pine species (A) and silvicultural treatments (B) applied in the sub-stands evaluated by FMP.

In the case of FMP1 in many of the sub-stands, seed-tree treatments were applied (Figure 2B) with intensive thinning due to the dominance of broadleaf trees species. However, Ramírez-Santiago [37] reported that there were no significant differences in regeneration with the single-tree selection method. This is because, although the seed-tree method suggests intensive extraction and opening of gaps, in the case of the Ixtlán de Juárez community, the process was not followed in the proper way. Because oaks did not have a stable market, they were not used, causing similar results in both silvicultural methods. The low utilization of oak was also attributed to the low cost per cubic meter, which did not exceed extraction costs [18,31].

Currently in the community, management of oaks is mostly aimed at the production of charcoal in brick kilns, with an approximate production of $140 \mathrm{t}$ per month. In addition, the energy characteristics of wood and charcoal of other broadleaf tree species have been evaluated [38], but the market conditions that allow the adequate use of these species are not yet available.

In the comparative analysis of the FMPs, the A0208 sub-stand (area of $30.78 \mathrm{ha}$ ) in the first plan partially received the seed-tree treatment, whereas, in the last two plans, it received strip clearcutting. The NT decreased from FMP2 to FMP3 (Figure 3A). However, $B A$ and $V o l$ increased in the genera Pinus and Quercus from FMP1 to FMP2 (Figure 3B,C), and, in the case of other broadleaf trees, it remained constant or did not differ noticeably. 
(A)

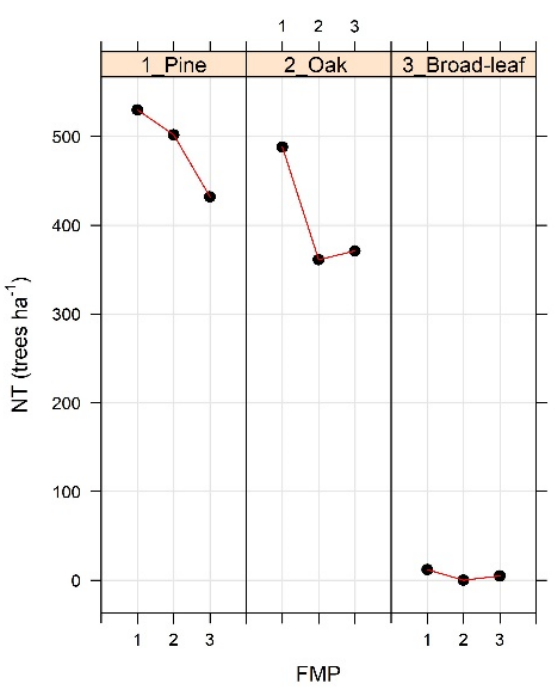

(B)

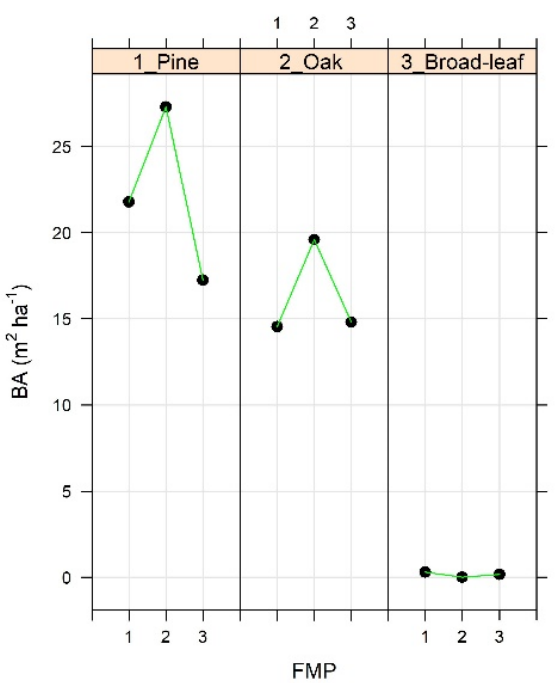

(C)

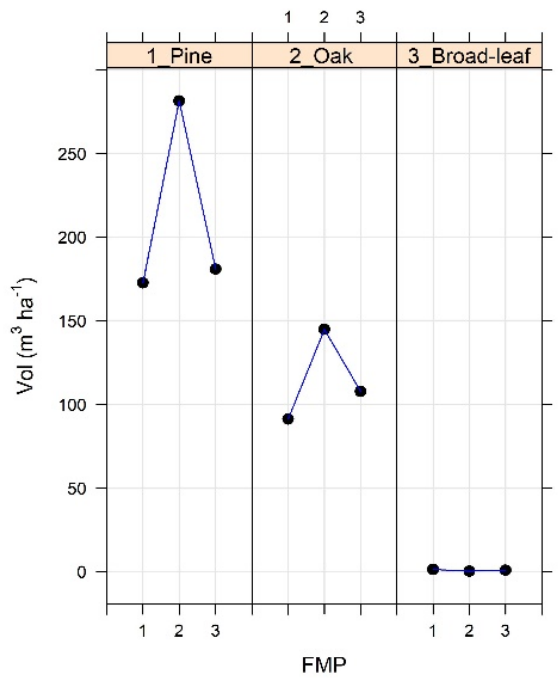

Figure 3. Comparison of the number of trees $(N T)(\mathbf{A})$, basal area $(B A)(\mathbf{B})$, and volume $(\mathrm{Vol})(\mathbf{C})$ under the three forest management plans (FMPs) in the A0208 sub-stand.

Intensive management such as the application of alternate strip clearcutting and thinning shows that, although NT decreases, Vol and BA tend to increase in the following cutting cycles due to greater spacing between individuals that reduces competition, to the litterfall that allows nutrients to be reincorporated into the forest floor, and to the capacity of the young stands to absorb these nutrients [39]. Forest growth is related to the level of forest site productivity and stand density. Dieler et al. [28] pointed out that productivity in biomass and volume is a central indicator of ecosystem functioning at the stand level, and that this productivity improves significantly with moderate thinning. On the other hand, the average diameter at breast height $(d b h)$ of the stand is strongly determined by density, and interventions such as thinning produce an instantaneous change in the value of this variable $[40,41]$. In addition, with the opening of gaps, seedlings tend to establish and grow rapidly. It is important to note that most pine species in the study area are shade-intolerant (except Pinus ayacahuite); thus, the implementation of these practices favors their growth and natural regeneration.

From the inventory for FMP3 (2015-2024), the 0.010 ha regeneration evaluation plots with strip clearcutting treatment generated an average regeneration density of 2392 trees $\cdot \mathrm{ha}^{-1}$ with an interval of 500-6500 trees $\cdot \mathrm{ha}^{-1}$, coinciding with the study carried

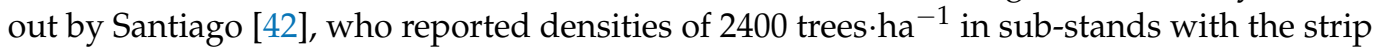
clearcutting treatment. On the other hand, Rodríguez-Ortiz et al. [43] classified the strip clearcutting areas as high regeneration $\left(>1500\right.$ trees $\left.\cdot \mathrm{ha}^{-1}\right)$ in the same study area. According to Moreno [44], the recommended natural regeneration is from 1283 to 2890 trees $^{-h^{-1}}{ }^{-1}$ therefore, we can state that the sub-stands where intensive silviculture is applied are within an appropriate range. In addition, this regeneration can be complemented with planting.

In the G0107 sub-stand (18.01 ha) of FMP1, the single-tree selection silvicultural treatment was applied, while the treatment in the two later FMPs was strip clearcutting. In FMP1, there was a larger stock of oaks; however, in FMP2, they were significantly reduced, favoring the growth of pine (Figure 4A), despite the fact that, in FMP1, the dominance in NT was oak, while BA (Figure 4B) and Vol (Figure 4C) were higher in pine. The different samplings for sub-stand G0107 showed a different dominant species; in the first, second, and third samplings, the reported species were Pinus teocote, Pinus leiophylla Schiede ex Schltdl. \& Cham., and Pinus patula, respectively. This reveals the species diversity in each sub-stand, since the application of silvicultural treatments modifies the conditions of diversity and abundance of the tree species present [24,28,36]. This situation is not only present in intensive methods; Solís-Moreno et al. [45] recorded that, in the forests 
of Durango, Mexico, the single-tree selection method also decreased tree diversity, since cuts were concentrated on only the Pinus genus with the best individual characteristics. Meanwhile, Yoshida et al. [46], in a forest managed with the single-tree selection method in Hokkaido, Japan, found a decrease in structural values and significant elements for biodiversity, such as large trees.

(A)

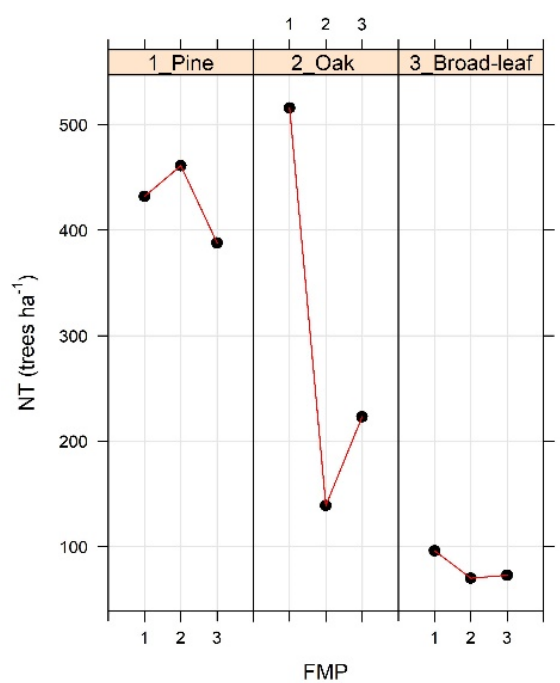

(B)

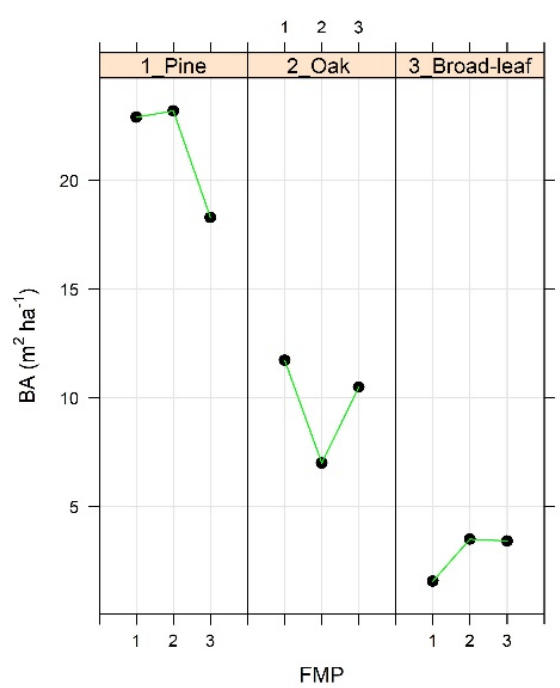

(C)

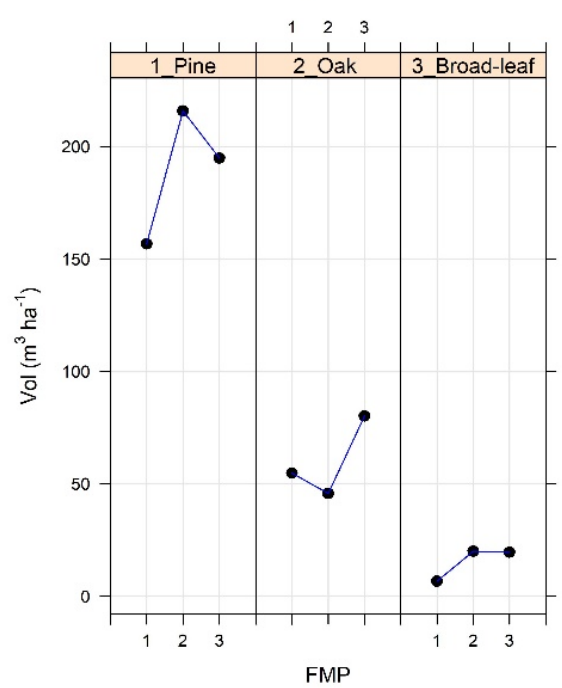

Figure 4. Comparison of number of trees $(N T)(\mathbf{A})$, basal area $(B A)(\mathbf{B})$, and volume $(\mathrm{Vol})(\mathbf{C})$ of the three forest management plans (FMPs) in the G0107 sub-stand.

In one study, Leyva-López et al. [47] found no differences in tree diversity between an area with another without forest management, and, although management could change the spatial structure of the forest, the species diversity was maintained. RamírezSantiago et al. [48] reported that non-intervened forests present greater diversity than managed forests, and that the mean annual increment in volume is similar in forests with seed-tree and group selection methods to a forest without management. Furthermore, Martínez-Cervantes [49] showed that, in the Ixtlán de Juárez forests, a great richness and diversity is maintained in areas with intensive forest management. In the G0107 sub-stand (Figure 4), the Simpson index (1-D) of 0.71 reveals a high biodiversity, mentioning that the species richness is concentrated in the genera Pinus and Quercus.

In the H0202 sub-stand (Figure 5) with 48.63 ha, the dominant species was Pinus patula. The first intervention was carried out by means of single-tree selection method, while the last two FMPs involved strip clearcutting; in the three forest inventories, the number of pine trees was similar. The number of oak and broadleaf trees varied greatly in the three forest inventories (Figure 5A). The total count of trees per hectare differed greatly: 1047 trees.ha ${ }^{-1}, 532$ trees.ha ${ }^{-1}$, and 699 trees.ha ${ }^{-1}$ in the first, second, and third inventories. This is because in the first intervention thinning and loggings were intensive and gave priority to the Pinus genus.

The volume of pine increased (Figure 5C) successively in the inventories of FMP2 and FMP3, respectively, while that of oak decreased from FMP1 to FMP2 but recovered in FMP3. The difference in volume of other broadleaf trees was small, although the NT decreased considerably. The increments also depend on the silvicultural treatment that is being applied, which directly influences growth in terms of both diameter and height, due to the conditions acquired in the forest site. In this case, the single-tree selection method was changed to strip clearcutting. 
(A)

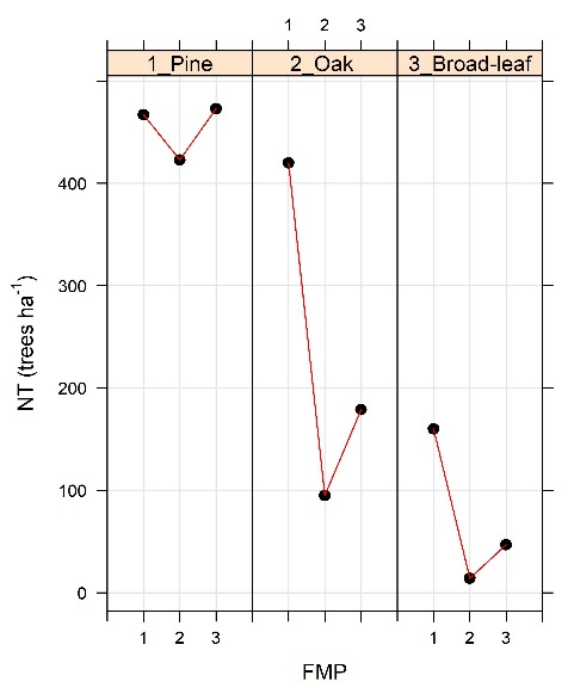

(B)

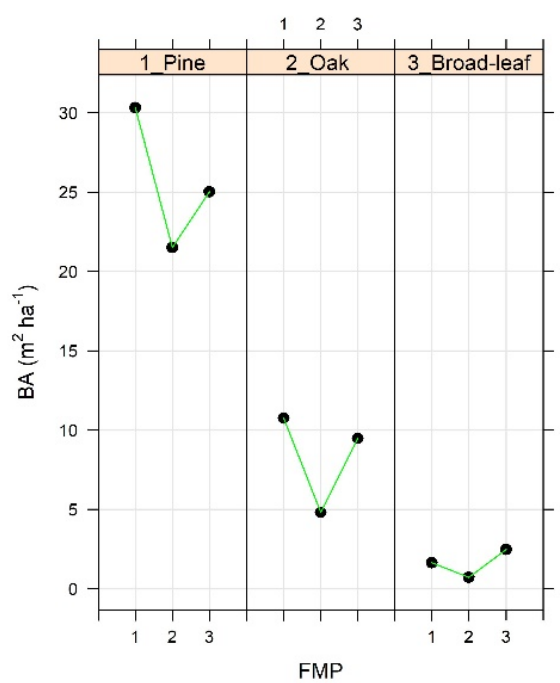

(C)

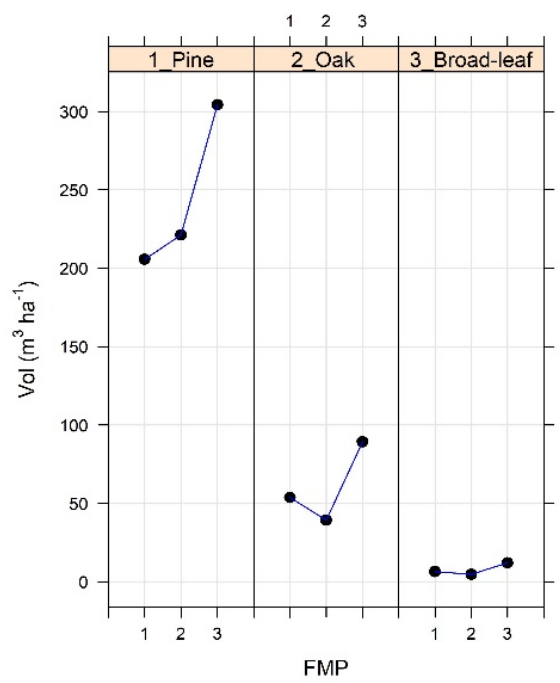

Figure 5. Comparison of number of trees (NT) (A), basal area $(B A)(\mathbf{B})$, and volume $(\mathrm{Vol})(\mathbf{C})$ of the three forest management plans (FMPs) in the H0202 sub-stand.

For pine-oak forests in Chihuahua, managed with the silvicultural development method (MDS), Núñez-López et al. [50] determined that, from the second measurement, the averages in $B A$, biomass, and growth produced were greater in the area with applied silvicultural treatments than in areas without management, verifying that the increases were larger in the forests where good silvicultural management was applied. This also depends on the site quality and its topographic and climatological conditions, in addition to the scheduled thinning regime, age of the stand, and the status of the residual trees [51].

Stand age also influences growth and increment. Santiago-García et al. [52] suggested that, in young stands of Pinus patula, thinning intensity should generally be strong and that the prescription should be based on stand density management diagrams, which would allow for better forest management. Intermediate cuttings allow productivity of the stand to increase. It has been shown that thinning and pruning can increase the value of the final harvest by increasing the merchantable volume, size, and wood quality [53].

The K0605 sub-stand (Figure 6) with a land area of 69.08 ha, in FMP1, was intervened with the seed-tree method, where most prominent tree species per hectare were oaks (783), pine (331), and other broad-leaf trees (11). In FMP2, the treatment used was single-tree selection, and, in this scenario, the number of pine trees already exceeded that of oaks, due to the treatments implemented in FMP1. In the FMP3 forest inventory, the trend continued to be a larger number of pines than oaks. Figure 6A shows the trend that each genus had in the different forest management plans and how, after FMP1, the number of pine and oak trees remained similar. The $B A$ in each FMP decreased in pine and oak, while, for other broadleaf trees, it increased (Figure 6B). In the case of $\mathrm{Vol}$ (Figure 6C), there was a $27.8 \%$ reduction in oak stocks for FMP2, while, for FMP3, there was an increase of $2.4 \%$ with respect to FMP2. With this, we can infer that strip clearcutting regularized the oak stocks in the sub-stand K0605 (because the difference was only $2.3 \mathrm{~m}^{3}$ ).

The purpose of subjecting the K0605 sub-stand to the seed-tree treatment in PMF1 may have been due to the dominance of oaks. However, this does not prevent the possibility of changing the silvicultural method in FMPs, because it depends on the characteristics that are present in the stand. Hernández-Díaz et al. [54] conducted an evaluation of volume recovery of the genus Pinus with even-aged and uneven-aged management systems. They found significant differences between the two methods, attributed to sampling intensity in the different measurements and a possible overestimation since, in some stands, the difference in volume between measurements is great. In the case of the sub-stands of Ixtlán 
de Juárez, Oaxaca, Mexico, there are differences in terms of volume, but the values are attributed to changes in silvicultural method.

(A)

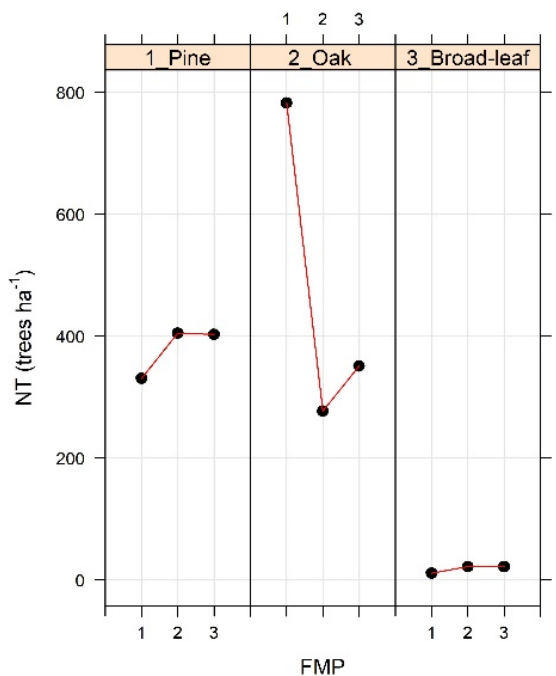

(B)

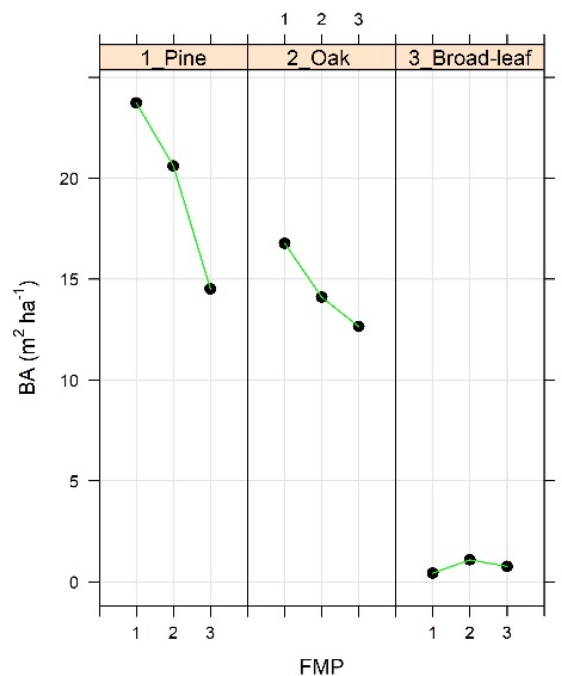

(C)

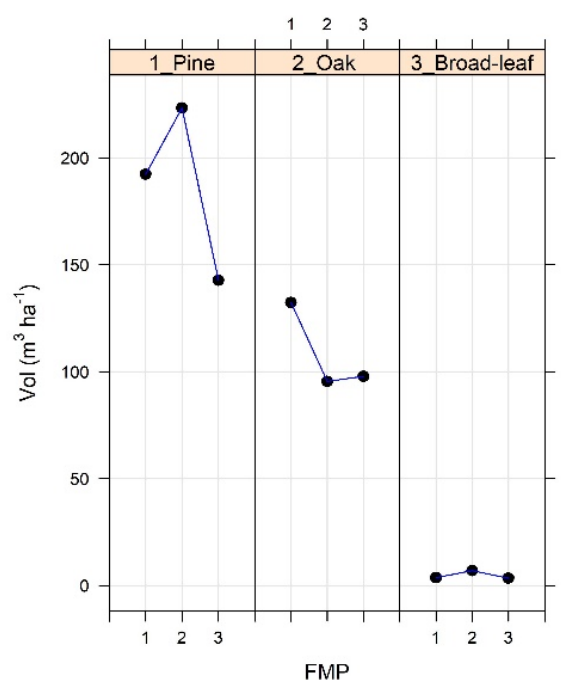

Figure 6. Comparison of number of trees (NT) (A), basal area $(B A)(\mathbf{B})$, and volume $(\mathrm{Vol})(\mathbf{C})$ of the three forest management plans (FMPs) in the K0605 sub-stand.

For the L0107 (Figure 7) and L0206 (Figure 8) sub-stands, the treatments applied were intensive. In the FMP1, the seed-tree method was applied, whereas FMP2 and FMP3 involved strip clearcutting. Moreover, in all inventories, the dominant species were the same. In the L0107 sub-stand, the dominant species was Pinus douglasiana, while, in L0206, the dominant species corresponded to Pinus oaxacana, both of great importance for the community.

(A)

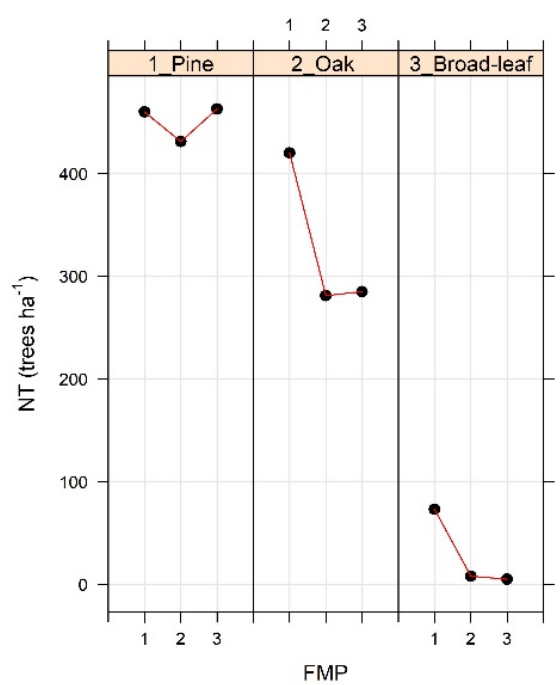

(B)

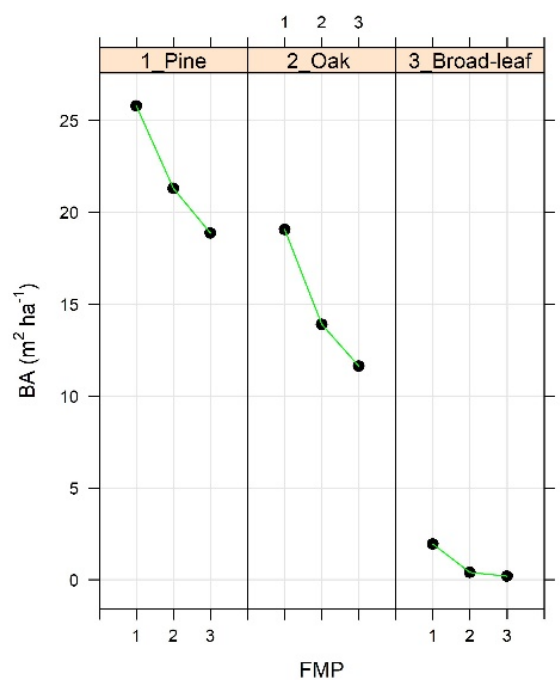

(C)

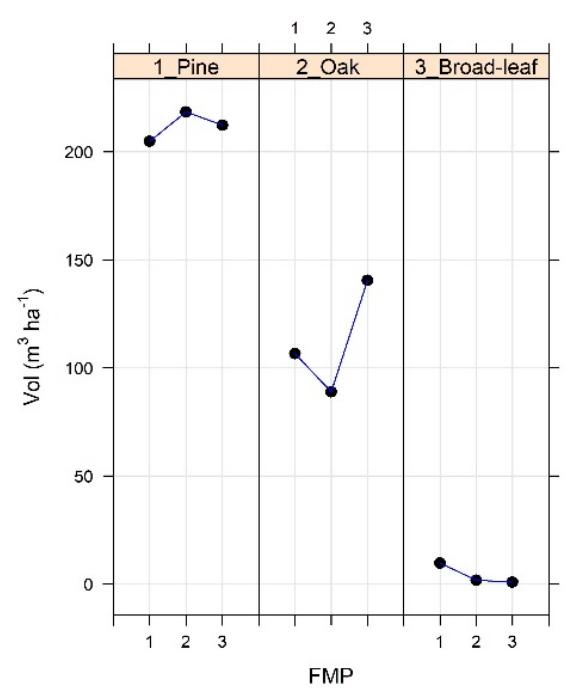

Figure 7. Comparison of number of trees (NT) (A), basal area (BA) (B), and volume (Vol) (C) of the three forest management plans (FMPs) in the L0107 sub-stand. 

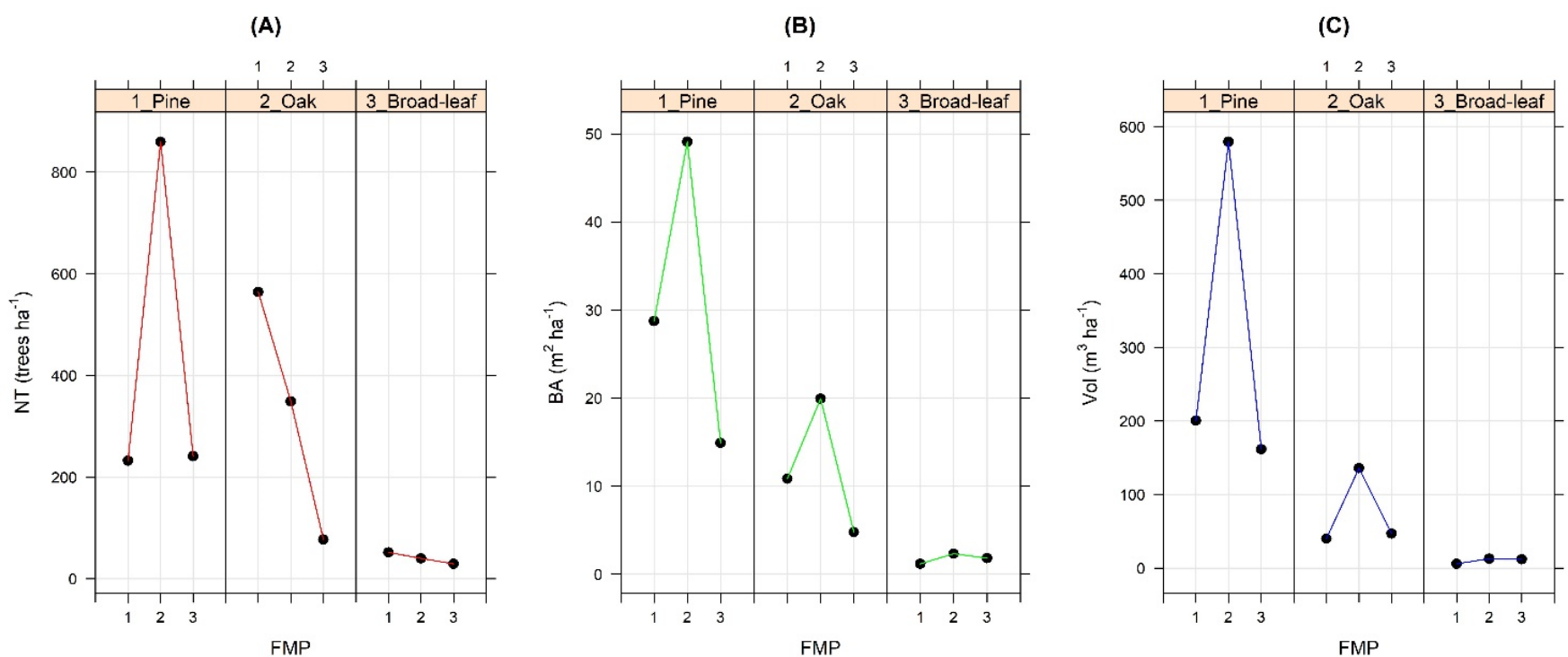

Figure 8. Comparison of number of trees $(N T)(\mathbf{A})$, basal area $(B A)(\mathbf{B})$, and volume $(\mathrm{Vol})(\mathbf{C})$ of the three forest management plans (FMPs) in the L0206 sub-stand.

Although the L0107 and L0206 sub-stands received the same silvicultural treatment, each presented a different trend. For example, in the L0107 sub-stand, there was a dominance of pine species, whereas, in the L0206, the sub-stand oak species dominated for FMP1. On the other hand, NT in the pine genus in the FMP2 sub-stand L0206 (Figure 8A) increased, whereas, for FMP3, it decreased from 860 trees $\cdot \mathrm{ha}^{-1}$ to 241 trees $\cdot \mathrm{ha}^{-1}$, although the number of pines was still higher than the number of oaks. On the other hand, the L0107 sub-stand remained constant in the three forest management plans, where the pine genus dominated.

Species dominance depends on the silvicultural treatment applied, in addition to the characteristics of the species in responding to natural regeneration and the conditions of the forest site. In the study area, even when different treatments were applied or a combination of the single-tree selection method with the strip clearcutting method was applied in the same sub-stand, the dominant species changed often or, in several cases, remained stable, as in the case of Pinus patula, because its relative abundance was higher [30]. This is also attributed to the fact that artificial regeneration was carried out in the community, and this was one of the main species produced in the nursery, because of its morphological characteristics and broad adaptation capacity [31,41]. In most of the sub-stands, the dominance of pines over oaks was noticeable; the treatments changed in each sub-stand, and each one had a different trend.

In the P0301 sub-stand (Figure 9) with an area of 59.84 ha, Pinus patula was the dominant species; in FMP3, its dominance was 30.4\%, while dominance of Quercus laurina Bonpl. was $18.7 \%$. It is worth mentioning that, in the three FMPs, the dominant species was Pinus patula, and the genus Pinus was dominant in all three. Regarding volume, this increased in each FMP for all genera.

In the Ixtlán de Juárez forest, several sub-stands are subjected to intensive silvicultural treatments, with opening of gaps to make regeneration more favorable and to achieve their establishment. These gaps benefit not only the Pinus genus but also other species, such as herbaceous plants that contribute to feeding the fauna [55,56]. According to STF [31], there are several rationales for the application of strip clearcutting, as in the cases of mature forests whose seed production has been reduced, forests that face difficulties for natural regeneration, and natural disasters such as fires, pests, or diseases. 
(A)

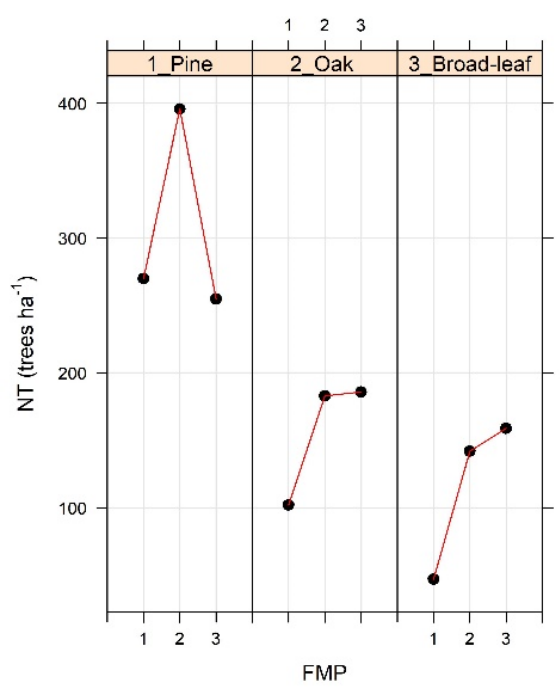

(B)

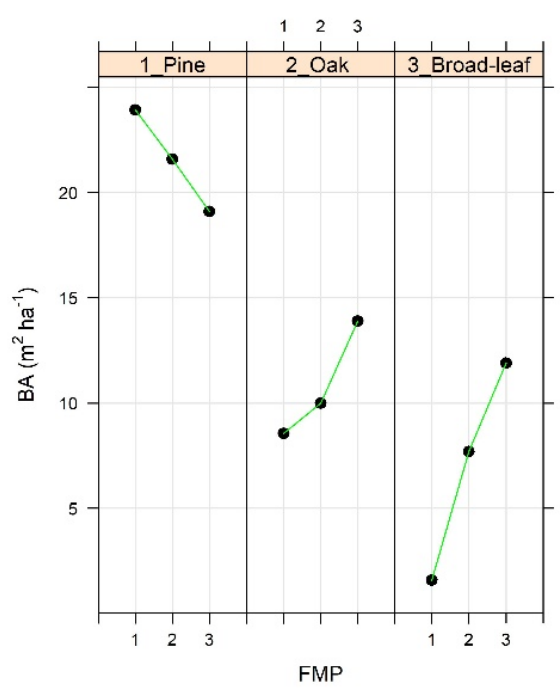

(C)

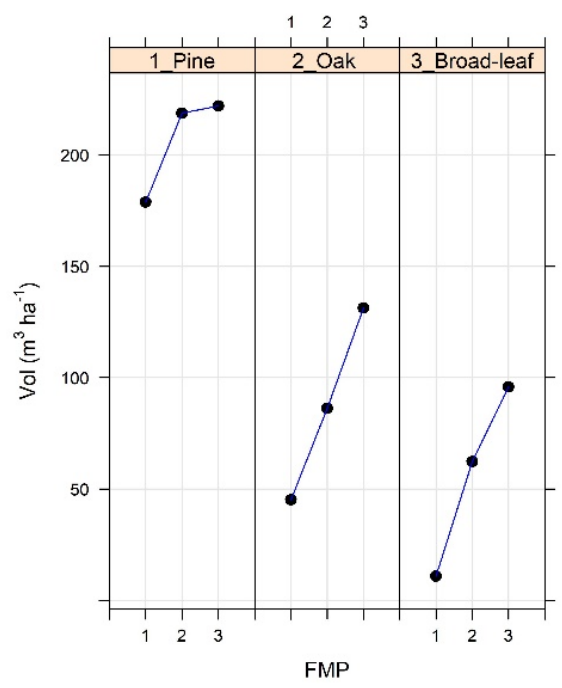

Figure 9. Comparison of number of trees $(N T)(\mathbf{A})$, basal area $(B A)(\mathbf{B})$, and volume $(\mathrm{Vol})(\mathbf{C})$ of the three forest management plans (FMPs) in the P0301 sub-stand.

In the application of strip clearcutting, guidelines are followed for execution of the treating and delimiting the strips, where the maximum land area is $3.5 \mathrm{ha}$, no more than $700 \mathrm{~m}$ long, with a maximum width of $60 \mathrm{~m}$ and a minimum width of $40 \mathrm{~m}$ [31]. However, in 2019, an 8 ha strip was harvested, the largest registered in the community forest. The justification for the size was to prevent infestation of neighboring stands by a defoliating insect that occurred in the community. In addition, complementary activities are performed: drawing contour lines, clearing, soil conservation works, reforestation, monitoring, pruning, and thinning, all essential to ensure the conservation of forests and good quality in the final products, regardless of the type of treatment carried out in each sub-stand or its condition. These activities also help prevent pests and diseases, as well as make the pertinent decisions. Recently, the community has faced infestations of defoliating insects and bark beetles. For their control and combat, guidelines should be followed for identification, determining the distribution, and defining phytosanitary treatments [57-59].

\subsection{Statistical Comparison of Sub-Stand Variables between FMPs}

Our results lead us to conclude that the intervention and the intensity of each silvicultural treatment differentially influenced the behavior of NT (Figure 10A), BA (Figure 10B), and $\mathrm{Vol}$ (Figure 10C). For example, in the first FMP, the number of trees was higher than in the two subsequent plans. In the same way, $B A$, which corresponds to volume, was higher in the second FMP. According to Van Deusen and Roesch [60], growth and removal of trees are critical for maintenance of the productive capacity of forest ecosystems, and these estimations are applied to a specific time interval determined by the inventory data, as in this case.

The $p$-values from the nonparametric Kruskal-Wallis test assumed values $<0.01$ for NT (Figure 10D), BA (Figure 10E), and Vol (Figure 10F) among the FMPs, indicating that the mean ranks of the evaluated groups were significantly different. These results give evidence that each applied silvicultural treatment generated a different response, and that management intensity positively influenced forest conservation. 
(A)

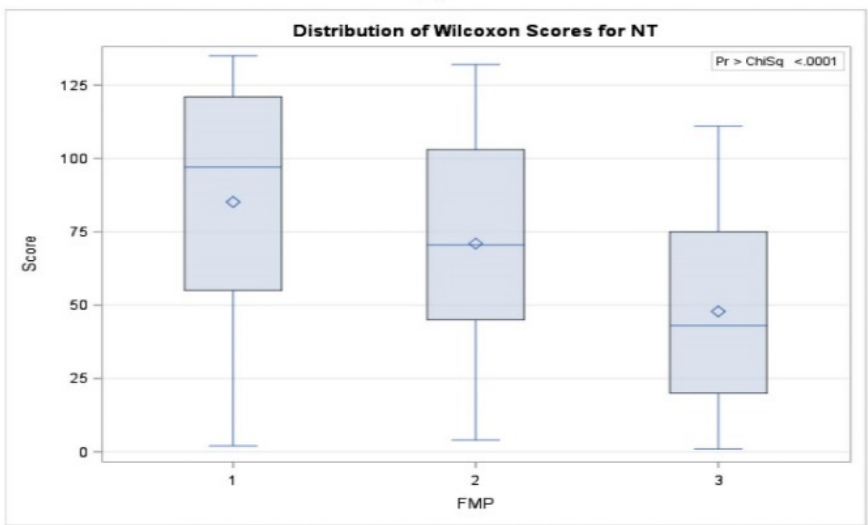

(C)

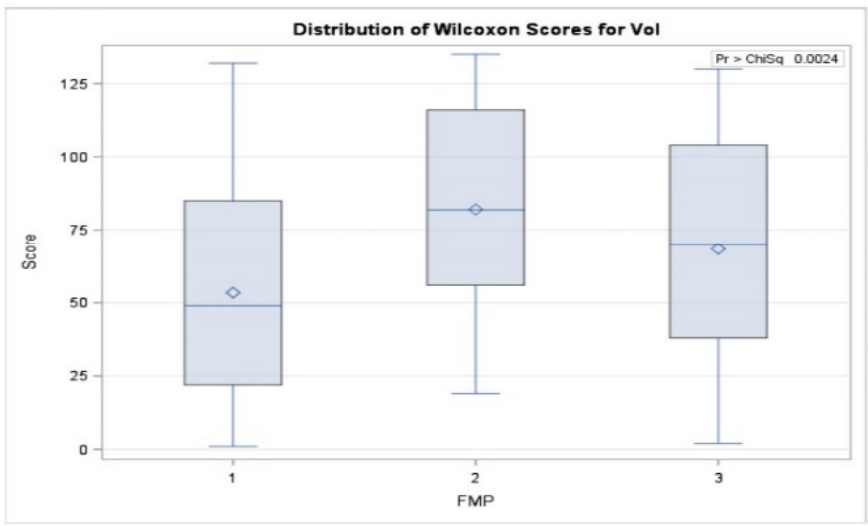

(E)

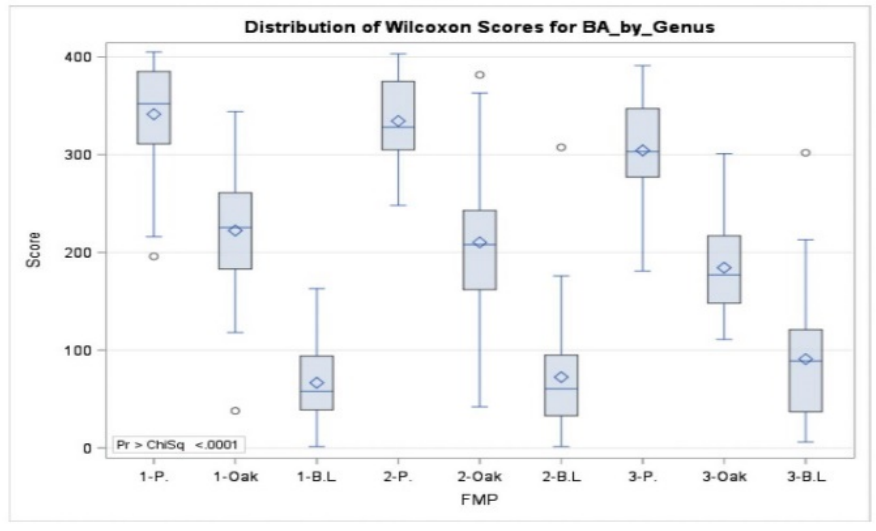

(B)

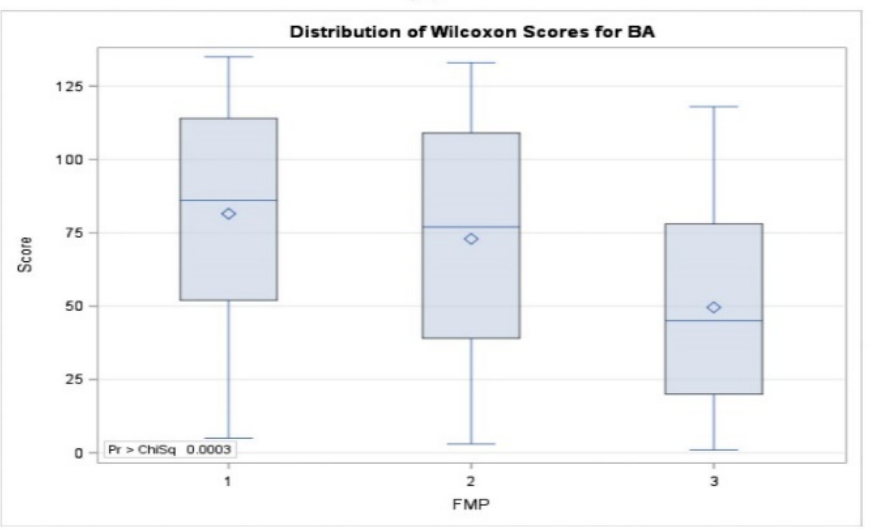

(D)

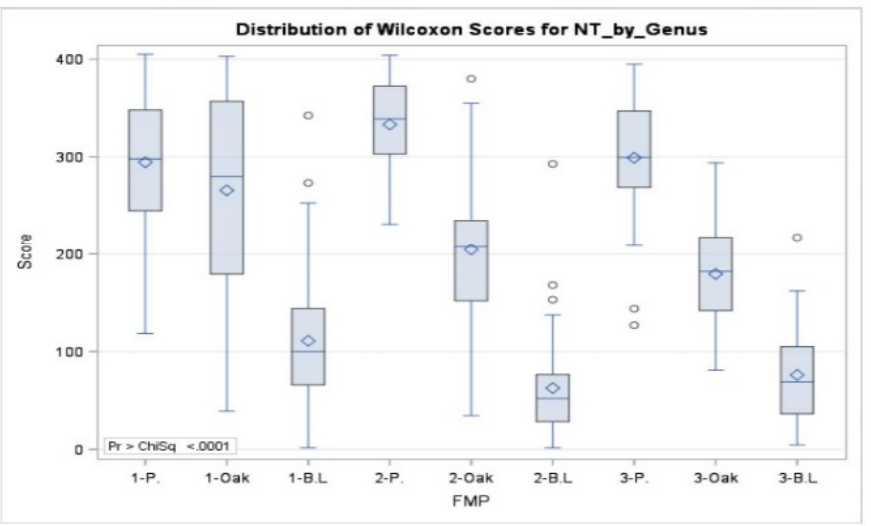

(F)

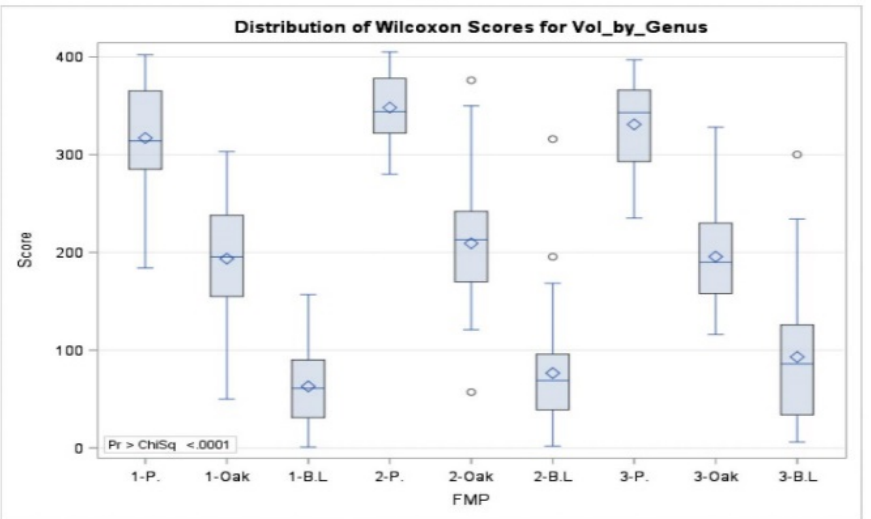

Figure 10. Boxplot diagrams for the number of trees (A), basal area (B), and volume (C) of the total by forest management plan (FMP). Boxplot diagrams for the number of trees (D), basal area (E), and volume (F) of the total by FMP in each genus. P: pine; B.L: broadleaf trees.

Regarding the NT, it was found that the population of oak species was larger in the first FMP and decreased in the second and third plans. In contrast, pine species increased in the two subsequent plans. In the same way, $B A$ and $V o l$ increased in each program, where the Pinus genus was dominant, displacing the dominance of the Quercus genus that was found in FMP1, such that the applied treatments gave priority to the regeneration of Pinus species, which are more economically important for the community. It was also shown that, if the NT decreased between FMPs, BA and $V o l$ between each genus were benefited. Broadleaf trees were maintained between silvicultural treatments regardless of the intensity of the harvest in each sub-stand. 
The results of the analysis carried out at the sub-stand level in the forests of Ixtlán de Juárez made it possible to demonstrate that, under community forest management and with greater management intensity, better productivity characteristics were obtained in volume and basal area, without affecting the richness of species. This is in agreement with Poudyal et al. [24] and Pagdee et al. [61], who pointed out that community forests perform better to promote productivity, richness, and composition of species, compared to other management regimes. They also maintain that this better performance can be explained by the security of land tenure, the effective application of rules and regulations, the frequency and regularity of forestry operations, effective local organization, the sensitivity of forest users to ecological aspects of forest management, and the expectation of obtaining socioeconomic benefits, among others. Therefore, community forest management constitutes an effective alternative to maintain the productive and conservation values of forest resources [13].

\section{Conclusions}

The compilation and analysis of data and information from three FMPs revealed how forestry has developed in the Ixtlán de Juárez community in Oaxaca, Mexico. The silvicultural treatments applied in FMP1 (seed-tree and single-tree selection methods) were somewhat conservative. In FMP2, strip clearcutting began, a method new not only to the community but also to the state of Oaxaca, Mexico, due to the visual impact it has and the intensity of the cutting that occurs. In the same way, the single-tree selection method was implemented in old growth stands. In FMP3, the method of strip clearcutting and single-tree selection was followed, to give continuity to the treatments applied in each sub-stand. With the application of a more intensive method, productivity increased in terms of harvested volume, as well as improved characteristics of individuals, with a lower impact on the residual trees or on trees adjacent to the harvested strips.

Natural regeneration also benefited from this intensive method, due to its opening of new gaps that allowed entry of light and rapid establishment of Pinus species, as well as growth of herbaceous plants and fruits used by wildlife. The combination of single-tree selection and strip clearcutting methods provided the necessary treatment to the forests, according to the characteristics that each sub-stand presented, taking care of the aspects required for regeneration and that led to conservation. In addition, the benefits of intensive cuttings are accepted and known in the community. Comparing the three forest management plans showed that intensive forest management generates many benefits for the community, such as increased productivity, conservation, and diversity, leading to higher economic income and ensuring a continuous source of employment in the community.

Supplementary Materials: The following are available online at https:/ /www.mdpi.com/article/10 .3390/f13030393/s1: Table S1. Comparison of sub-stand variables of the three forest management plans (FMPs).

Author Contributions: Conceptualization, W.S.-G. and L.B.-P.; data curation, L.B.-P.; formal analysis, W.S.-G., L.B.-P., G.R.-O., G.Q.-B., F.R.-A., M.E.S.-M., E.S.-G., T.L.-P., M.C.-P., and M.d.J.G.-G.; investigation, W.S.-G., L.B.-P., G.R.-O., G.Q.-B., F.R.-A., M.E.S.-M., E.S.-G., T.L.-P., M.C.-P., and M.d.J.G.-G.; methodology, W.S.-G. and L.B.-P.; project administration, W.S.-G.; resources, W.S.-G. and E.S.-G.; software, W.S.-G.; validation, W.S.-G. and E.S.-G.; writing-original draft, W.S.-G. and L.B.-P.; writing-review and editing, W.S.-G., L.B.-P., G.R.-O., G.Q.-B., F.R.-A., M.E.S.-M., E.S.-G., T.L.-P., M.C.-P., and M.d.J.G.-G. All authors have read and agreed to the published version of the manuscript.

Funding: This research received no external funding.

Data Availability Statement: The data used in the article are available in the Supplementary Materials.

Acknowledgments: We thank the community of Ixtlán de Juárez and the technical forestry crew for the facilities granted for the realization of this study.

Conflicts of Interest: The authors declare no conflict of interest. 


\section{References}

1. Bray, D.B.; Merino-Pérez, L.; Barry, D. Chapter 1: Community Managed in the Strong Sense of the Phrase: The Community Forest Enterprises of Mexico. In The Community Forests of Mexico: Managing for Sustainable Landscapes; University of Texas Press: Austin, TX, USA, 2005; pp. 1-26. ISBN 978-0-292-79692-8.

2. Klooster, D.; Ambinakudige, S. Chapter 13: The Global Significance of Mexican Community Forestry. In The Community Forests of Mexico: Managing for Sustainable Landscapes; University of Texas Press: Austin, TX, USA, 2005; pp. 303-334. ISBN 978-0-292-79692-8.

3. Torres-Rojo, J.M.; Moreno-Sánchez, R.; Mendoza-Briseño, M.A. Sustainable forest management in Mexico. Curr. For. Rep. 2016, 2, 93-105. [CrossRef]

4. [CONAFOR] Comisión Nacional Forestal El Sector Forestal Mexicano en Cifras 2020. Available online: http://www.gob.mx/ conafor/documentos/el-sector-forestal-mexicano-en-cifras-2020 (accessed on 6 June 2021).

5. de los Santos-Posadas, H.M.; Valdez-Lazalde, J.R.; Torres-Rojo, J.M. Chapter 23-San Pedro El alto community forest, Oaxaca, Mexico. In Forest Plans of North America; Siry, J.P., Bettinger, P., Merry, K., Grebner, D.L., Boston, K., Cieszewski, C., Eds.; Academic Press: San Diego, CA, USA, 2015; pp. 199-208. ISBN 978-0-12-799936-4.

6. Madrid, L.; Núñez, J.M.; Quiroz, G.; Rodríguez, Y. La propiedad social forestal en México. Investig. Ambient. $2009,1,179-196$.

7. Frey, G.E.; Cubbage, F.; Holmes, T.P.; Reyes-Retana, G.; Davis, R.R.; Megevand, C.; Rodríguez-Paredes, D.; Kraus-Elsin, Y.; Hernández-Toro, B.; Chemor-Salas, D.N. Competitiveness, certification, and support of timber harvest by community forest enterprises in Mexico. For. Policy Econ. 2019, 107, 101923. [CrossRef]

8. Mathews, A.S. Mexican forest history. J. Sustain. For. 2002, 15, 17-28. [CrossRef]

9. [FAO] Food and Agriculture Organization Estado y Tendencias de La Ordenación Forestal En 17 Países de América Latina Por Consultores Forestales Asociados de Honduras (FORESTA). Documentos de Trabajo Sobre Ordenación Forestal; Documento de Trabajo FM/26; Servicio de Desarrollo de Recursos Forestales, Dirección de Recursos Forestales, FAO, Roma. Available online: https:/ /www.fao.org/3/j2628s/J2628S13.htm\#P1316_206954 (accessed on 6 June 2021).

10. Moeliono, M.; Thuy, P.T.; Bong, I.W.; Wong, G.Y.; Brockhaus, M. Social Forestry-why and for whom? A comparison of policies in Vietnam and Indonesia. For. Soc. 2017, 1, 78-97. [CrossRef]

11. Cedeño Gilardi, H.; Pérez Salicrup, D.R. La Legislación Forestal y Su Efecto En La Restauración En México. Instituto Nacional de Ecología y Cambio Climático. Available online: http:/ /www2.inecc.gob.mx/publicaciones2/libros/467/cedenoyperez.html (accessed on 10 June 2021).

12. Aguirre-Calderón, O.A. Manejo Forestal en el Siglo XXI. Madera Bosques 2015, 21, 17-28. [CrossRef]

13. Rodríguez-Zúñiga, J.; González-Guillén, M.D.J.; Valtierra-Pacheco, E. Las empresas forestales comunitarias en la región de la Mariposa Monarca, México: Un enfoque empresarial. Bosque (Valdivia) 2019, 40, 57-69. [CrossRef]

14. Bray, B.; Merino-Pérez, L. The rise of community forestry in Mexico: History, concepts, and lessons learned from twenty-five years of community timber production. In A Report in partial fulfillment of Grant; The Ford Foundation: New York, NY, USA, 2002.

15. Wright, D.A.; Leighton, A.D. Forest utilization in Oaxaca. J. Sustain. For. 2002, 15, 67-79. [CrossRef]

16. Bray, D.B.; Merino-Pérez, L. La Experiencia de las Comunidades Forestales en México: Veinticinco Años de Silvicultura y Construcción de Empresas Forestales Comunitarias; Instituto Nacional de Ecología: Distrito Federal, Mexico, 2004; ISBN 978-968-817-656-6.

17. TIASA. Programa de Manejo Forestal Para El Predio de La Comunidad de Ixtlán de Juárez, Oaxaca; TIASA: Oaxaca, Mexico, 1993.

18. Ganz, D.J.; Burckle, J.H. Forest utilization in the Sierra Juarez, Oaxaca, Mexico. J. Sustain. For. 2002, 15, 29-49. [CrossRef]

19. Asbjornsen, H.; Ashton, M.S. Community forestry in Oaxaca, Mexico. J. Sustain. For. 2002, 15, 1-16. [CrossRef]

20. Chapela, F. Chapter 5: Indigenous Community Forest Management in the Sierra Juárez, Oaxaca. In The Community Forests of Mexico: Managing for Sustainable Landscapes; University of Texas Press: Austin, TX, USA, 2005; pp. 89-110. ISBN 978-0-292-79692-8.

21. Chaudhary, A.; Burivalova, Z.; Koh, L.P.; Hellweg, S. Impact of forest management on species richness: Global meta-analysis and economic trade-offs. Sci. Rep. 2016, 6, 23954. [CrossRef] [PubMed]

22. Machar, I.; Simon, J.; Rejsek, K.; Pechanec, V.; Brus, J.; Kilianova, H. Assessment of forest management in protected areas based on multidisciplinary research. Forests 2016, 7, 285. [CrossRef]

23. Liang, J.; Crowther, T.W.; Picard, N.; Wiser, S.; Zhou, M.; Alberti, G.; Schulze, E.-D.; McGuire, A.D.; Bozzato, F.; Pretzsch, H.; et al Positive biodiversity-productivity relationship predominant in global forests. Science 2016, 354, aaf8957. [CrossRef] [PubMed]

24. Poudyal, B.H.; Maraseni, T.; Cockfield, G. Impacts of forest management on tree species richness and composition: Assessment of forest management regimes in Tarai landscape Nepal. Appl. Geogr. 2019, 111, 102078. [CrossRef]

25. Pretzsch, H.; Block, J.; Dieler, J.; Dong, P.H.; Kohnle, U.; Nagel, J.; Spellmann, H.; Zingg, A. Comparison between the productivity of pure and mixed stands of Norway spruce and European beech along an ecological gradient. Ann. For. Sci. 2010, 67, 712. [CrossRef]

26. Pretzsch, H.; Bielak, K.; Block, J.; Bruchwald, A.; Dieler, J.; Ehrhart, H.-P.; Kohnle, U.; Nagel, J.; Spellmann, H.; Zasada, M.; et al. Productivity of mixed versus pure stands of oak (Quercus petraea (Matt.) Liebl. and Quercus robur L.) and European beech (Fagus sylvatica L.) along an ecological gradient. Eur. J. For. Res. 2013, 132, 263-280. [CrossRef]

27. Schall, P.; Ammer, C. How to quantify forest management intensity in Central European forests. Eur. J. For. Res. 2013, 132, 379-396. [CrossRef]

28. Dieler, J.; Uhl, E.; Biber, P.; Müller, J.; Rötzer, T.; Pretzsch, H. Effect of forest stand management on species composition, structural diversity, and productivity in the temperate zone of Europe. Eur. J. For. Res. 2017, 136, 739-766. [CrossRef] 
29. Soto Cervantes, J.A.; Padilla Martínez, J.R.; Domínguez Calleros, P.A.; Carrillo Parra, A.; Rodríguez Laguna, R.; Pompa García, M.; García Montiel, E.; Corral Rivas, J.J. Effect of Four Silvicultural Treatments on Timber Production in a Forest in Durango. Rev. Mex. Cienc. For. 2021, 12, 56-80. [CrossRef]

30. Santiago-García, W.; Jacinto-Salinas, A.H.; Rodríguez-Ortiz, G.; Nava-Nava, A.; Santiago-García, E.; Ángeles-Pérez, G.; Valle, J.R.E.-D. Generalized height-diameter models for five pine species at Southern Mexico. For. Sci. Technol. 2020, 16, 49-55. [CrossRef]

31. [STF] Servicios Técnicos Forestales de Ixtlán de Juárez. Programa de Manejo Forestal Para El Aprovechamiento y Conservación de Los Recursos Forestales Maderables de Ixtlán de Juárez. Ciclo de Corta 2015-2024; Servicios Técnicos Forestales de Ixtlán de Juárez: Oaxaca, Mexico, 2015.

32. Kruskal, W.H.; Wallis, W.A. Use of ranks in one-criterion variance analysis. J. Am. Stat. Assoc. 1952, 47, 583-621. [CrossRef]

33. SAS Institute. SAS Institute Base SAS 9.4 Procedures Guide: Statistical Procedures; SAS Institute: Cary, NC, USA, 2017.

34. Sedgwick, P. Multiple significance tests: The Bonferroni correction. BMJ 2011, 344, e509. [CrossRef]

35. R Development Core Team. R: A Language and Environment for Statistical Computing; R Foundation for Statistical Computing: Vienna, Austria, 2021.

36. Castellanos-Bolaños, J.F.; Treviño-Garza, E.J.; Aguirre-Calderón, O.A.; Jiménez-Pérez, J.; Velázquez-Martínez, A. Diversidad arbórea y estructura espacial de bosques de pino-encino en Ixtlán de Juárez, Oaxaca. Rev. Mex. Cienc. For. 2010, 1, 39-52.

37. Ramírez Santiago, R. Efectos de la Aplicación de dos Métodos de Regeneración Sobre la Estructura, Diversidad y Composición de un Bosque de Pino-Encino en la Sierra Juárez de Oaxaca, México. Master's Thesis, Centro Agronómico Tropical de Investigaciones y Enseñanza (CATIE), Turrialba, Costa Rica, 2006.

38. Ruiz-Aquino, F.; Ruiz-Ángel, S.; Santiago-García, W.; Fuente-Carrasco, M.E.; Sotomayor-Castellanos, J.R.; Carrillo-Parra, A. Energy characteristics of wood and charcoal of selected tree species in Mexico. WOOD Res. 2019, 64, 71-82.

39. Pérez-Alavez, Y.; Rodríguez-Ortiz, G.; Santiago-García, W.; Campos-Angeles, G.V.; Valle, J.R.E.-D.; Martin, M.P. Effect of thinning intensity on litterfall biomass and nutrient deposition in a naturally regenerated pinus pseudostrobus lind. Forest in Oaxaca, Mexico. J. Sustain. For. 2021, 1-18. [CrossRef]

40. Santiago-García, W.; Santos-Posadas, H.M.D.L.; Ángeles-Pérez, G.; Valdez-Lazalde, J.R.; Corral-Rivas, J.J.; Rodríguez-Ortiz, G.; Santiago-García, E. Modelos de crecimiento y rendimiento de totalidad del rodal para Pinus patula. Madera Bosques 2015, 21, 95-110. [CrossRef]

41. Santiago-García, W.; Pérez-López, E.; Quiñonez-Barraza, G.; Rodríguez-Ortiz, G.; Santiago-García, E.; Ruiz-Aquino, F.; TamaritUrias, J.C. A Dynamic system of growth and yield equations for pinus patula. Forests 2017, 8, 465. [CrossRef]

42. Santiago, G.E. Regeneración Natural Bajo El Método de Matarrasa En Franjas En Ixtlán de Juárez, Oaxaca. Informe Final de Residencia Profesional; Instituto Tecnológico Del Valle de Oaxaca: Nazareno, Xoxocotlán; Oaxaca, México, 2010.

43. Rodríguez-Ortiz, G.; García-Aguilar, J.Á.; Leyva-López, J.C.; Ruiz-Díaz, C.; Valle, J.R.E.-D.; Santiago-García, W. Biomasa estructural y por compartimentos en regeneración de Pinus patula en áreas con matarrasa. Madera Bosques 2019, 25, 25. [CrossRef]

44. Moreno, G.D.A. La Regeneración de Pino Como Sustentabilidad Del Sistema de Manejo Integral (SIMANIN) En Tapalpa, Jalisco; INIFAPSAGARPA: Guadalajara, México, 2001.

45. Moreno, R.S.; Aguirre-Calderón, Ó.A.; Treviño-Garza, E.J.; Pérez, J.J.; Ybarra, E.J.; Corral-Rivas, J. Efecto de dos tratamientos silvícolas en la estructura de ecosistemas forestales en Durango, México. Madera Bosques 2006, 12, 49-64. [CrossRef]

46. Yoshida, T.; Naito, S.; Nagumo, M.; Hyodo, N.; Inoue, T.; Umegane, H.; Yamazaki, H.; Miya, H.; Nakamura, F. Structural complexity and ecosystem functions in a natural mixed forest under a single-tree selection silviculture. Sustainability 2017, 9, 2093. [CrossRef]

47. Leyva-López, J.C.; Velázquez-Martínez, A.; Ángeles-Pérez, G. Patrones de diversidad de la regeneración natural en rodales mezclados de pinos. Rev. Chapingo Ser. Cienc. For. Ambiente 2010, 16, 227-240. [CrossRef]

48. Santiago, R.R.; Ángeles Pérez, G.; De La Rosa, P.H.; Alcalá, V.M.C.; Escalante, O.P.; Clark-Tapia, R. Efectos del aprovechamiento forestal en la estructura, diversidad y dinámica de rodales mixtos en la Sierra Juárez de Oaxaca, México. Madera Bosques 2019, 25, 25. [CrossRef]

49. Martínez-Cervantes, E. Estructura y Dinámica de Bosques Con Manejo Forestal En Ixtlán de Juárez, Oaxaca. Forestry Engineer; Universidad de la Sierra Juárez.: Oaxaca, México, 2019.

50. Núñez-López, D.; Wong, G.J.C.; Paz, P.F. Dinámica de La Producción de Biomasa Por Efecto de Las Intervenciones Silvícolas Aplicadas En Bosques Regulares Del Ejido El Largo y Anexos En Chihuahua. In Proceedings of the VI Simposio Internacional del Carbono en México, Villahermosa, México, 20-22 May 2015; p. 81.

51. Del Río, M.; Calama, R.; Canellas, I.; Roig, S.; Montero, G. Thinning intensity and growth response in SW-European Scots pine stands. Ann. For. Sci. 2008, 65, 308. [CrossRef]

52. Santiago-García, W.; De los Santos-Posadas, H.M.; Ángeles-Pérez, G.; Valdez-Lazalde, J.R.; Del Valle-Paniagua, D.H.; Corral-Rivas, J.J. Self-Thinning and Density Management Diagrams for Pinus Patula Fitted under the Stochastic Frontier Regression Approach. Agrociencia 2013, 47, 75-89.

53. Missanjo, E.; Kamanga-Thole, G. Effect of first thinning and pruning on the individual growth of Pinus patula tree species. J. For Res. 2015, 26, 827-831. [CrossRef]

54. Hernández-Díaz, J.C.; Corral-Rivas, J.J.; Quiñones-Chávez, A.; Bacon-Sobbe, J.R.; Vargas-Larreta, B. Evaluación del manejo forestal regular e irregular en bosques de la Sierra Madre Occidental. Madera Bosques 2008, 14, 25-41. [CrossRef] 
55. Holladay, C.-A.; Kwit, C.; Collins, B. Woody regeneration in and around aging southern bottomland hardwood forest gaps: Effects of herbivory and gap size. For. Ecol. Manag. 2006, 223, 218-225. [CrossRef]

56. Millington, J.D.; Walters, M.B.; Matonis, M.S.; Liu, J. Modelling for forest management synergies and trade-offs: Northern hardwood tree regeneration, timber and deer. Ecol. Model. 2012, 248, 103-112. [CrossRef]

57. Suárez-Mota, M.E.; Pacheco-García, M.M.; Cristóbal-Angulo, O.P.; Antúnez, P.; Santiago-García, W.; Bautista-Juárez, I. La plaga defoliadora Zadiprion falsus Smith en la Sierra Norte de Oaxaca, México: Estado actual y perspectivas. Agro Product. 2018, 11, 35-41.

58. Aguirre-Hidalgo, V.; Casasola-González, J.A.; Alfonso-Corrado, C.; Santiago-García, E.; Clark-Tapia, R. Registro y ecología de Zadiprion howdeni (Hymenoptera: Diprionidae) en Ixltán de Juárez, Oaxaca. Madera Bosques 2020, 26. [CrossRef]

59. Suárez-Mota, M.E.; Angulo, O.P.C.; Santiago-García, W.; Ruiz-Aquino, F. Distribution of the defoliating pest zadiprion falsus: An análisis of overlapping niches of its hosts in Mexico. Èntomol. Am. 2021, 127, 5-11. [CrossRef]

60. Van Deusen, P.C.; Roesch, F.A. Alternative definitions of growth and removals and implications for forest sustainability. For. Int. J. For. Res. 2008, 81, 177-182. [CrossRef]

61. Pagdee, A.; Kim, Y.-S.; Daugherty, P.J. What makes community forest management successful: A meta-study from community forests throughout the world. Soc. Nat. Resour. 2006, 19, 33-52. [CrossRef] 